\title{
Erratum to: Postcolonial Suicide Among Inuit in Arctic Canada
}

\author{
Michael J. Kral
}

Published online: 10 April 2012

(C) Springer Science+Business Media, LLC 2012

\section{Erratum to: Cult Med Psychiatry DOI 10.1007/s11013-012-9253-3}

Figure 1. Suicide in Nunavut, 1975-2010 is missing a citation. Data were obtained from the Offices of the Chief Coroners of the Northwest Territories and Nunavut. Special thanks to Cathy Menard, Chief Coroner of the Northwest Territories, and to Padma Suramala and Tim Neily, present and past Chief Coroners of Nunavut. Dr. Kral acknowledges that some of the data obtained for 1975 to April 1, 1999 were compiled by Jack Hicks, a member of The Working Group For A Suicide Prevention Strategy For Nunavut and a Ph.D. student at Ilisimatursarfik (The University of Greenland).

The Nunavut Suicide Prevention Strategy is not named in the text, though it is referenced in the text during a discussion of the second 2010 report. The strategy may be found on the website of the Inuit representative organization Nunavut Tunngavik Inc. at http://www.tunngavik.com/wp-content/uploads/2010/10/201010-26-nunavut-suicide-prevention-strategy-english.pdf

The online version of the original article can be found under doi:10.1007/s11013-012-9253-3.

\footnotetext{
M. J. Kral (ه)

Department of Psychology, University of Illinois at Urbana-Champaign, 603 E. Daniel Street, Champaign, IL 61822, USA

e-mail: mkral@illinois.edu
}

\section{J. Kral}

University of Toronto, Toronto, ON, Canada 